\title{
CORRESPONDENCE
}

\section{Italian Science}

SiR,-In Italy, research is almost completely in the hands of the National Council of Research (CNR), founded by Mussolini on November 18, 1923 (see $L a$ Ricerca Scientifica, 1945, p. 108). According to OCSE's experts, the CNR can be compared-as far as its juridic nature is concerned-to "an institution with a corporative nature, comparable with those professional orders which have multiplied during the fascist period". At present all financing has been suspended, and many applications have been rejected, even when some months ago it seemed that they had been approved. As for the applications which have been approved, the funds are still to be found on the budget of 1970 and some say that money for the research going on at present will not be paid until next spring. Young scientists and technicians are therefore obliged to abandon the universities, and projects (some international) must be cancelled in our programmes (supposing one may speak of "programmes" in Italy). And unfortunately this is not the first time we have had serious administrative trouble, though the CNR has at its disposal more employees than research workers.

One example is that of the International Biological Programme (or IBP), which for us was the first timid approach towards ecology, more especially productivity: whereas in other countries the IBP has seen and is still seeing beautiful research, which will go on until 1972, in Italy they say it is over. Whereas abroad many contributions have been published in the field of IBP, here there has been a very poor production. Even the results of the exploration of the small Italian islands, included in the CT programme of IBP, are extremely poor.

This contrasts strongly with the results Italian scientists had achieved in the field of the International Geophysical Year (1955), only 10 years after World War II. We cannot help thinking therefore that our Government's scientific policy is fundamentally very bad.

Useless to say that this has been well known abroad for several years: suffice it to quote Di Ferrante (Science, 161, 451; 1968), Consolazio (ibid., 133; 1968), Greenberg (ibid., 167, 1706; 1970), and Survey of Science in Europe (Nature, 226, $1016 ; 1970)$ who give a very clear and exact description of Italian scientific policy, especially in calling the members of CNR "self serving advisers" (Di
Ferrante, p. 451). We must not forget, however, that already in 1955 a member of CNR, Professor Di Mattei, had made a very clear critique of its policy, in which he says (La Ricerca Scientifica, 25, 2372; 1955) "the Committee (for Biology and Medicine) has over all limited itself to a mere paternalistic distribution of the funds it had at its disposition, and has not confronted the great scientific problems which should have been the highest task of its financial policy".

What our responsible men are not able to do is to split completely the research in the universities (which are entirely state entities, depending on the Ministry of Education) and that in the CNR centres (which depend on the Presidence of Ministers), keeping two independent budgets, with no interchange or osmosis possible between the two. The full separation of powers and of men would be particularly necessary in a country such as Italy, which is famous all over the world for its "camarillas", mafia, "Baronie", clientelism, and so on. Of course the stronger the relationships between university and CNR, the easier the clientelism between the "owners" of CNR and the university institutes, which today depend for research completely on the former because practically all the members of CNR (presidents of committees, sub-committees, work groups, sections, and so on) are also professors in the chair at some university. With the last events of the CNR, the fear that all of us (university workers) have to be turned in post-lyceum teachers instead of research workers is stronger and stronger and quite justified. On the other hand, the political situation of the country (see a series of articles by P. Nourry and P. Bois in Le Figaro, the last of which was published on September 22) does not permit any sort of optimism in this field.

Yours faithfully,

Giorgio MarcuzzI

The University of Padova

\section{Suckling Etymology}

SIR,-In his letter (Nature, 233, 73; 1971) Mr Spratling complains that a communication $^{1}$ which several co-signatories and I sent to you some 20 years ago has been the cause of the confusion he has recently experienced in fairly extensive reading on the topic of suckling. We are apparently to blame because we used the verb "to suckle" in a manner contrary to the usage of Shakespeare and of that found in the Bible.

English usage never stands still. It is nearly 300 years since the verb "to suckle" began to be used to denote the activity of the young as well as that of the lactating mother. This extension of meaning has caused ambiguities. It was because of this long-standing ambiguity that the signatories of the letter, who were then all working in the field of lactational physiology and well aware of the difficulties that could arise, suggested that it might be helpful if authors of scientific papers were to restrict the use of this verb to denote only one activity and since its commonest usage in contemporary papers was with reference to the activity of the young we suggested that it be so restricted. $\mathrm{Mr}$ Spratling is, of course, equally entitled to suggest that the meaning be restricted to the activity of the mother provided that he indicates, as we did, that he uses the word in a restricted sense. To imply, however, that his choice is the only correct usage is, at the present time, nonsense. He should get an up to date dictionary and put Shakespeare on the shelf.

In Mr Spratling's description "the calf sucks the cow" the use of the verb "to suck" is unfortunate, not in this instance because of any change in usage since Shakespeare's time but because there have been some advances ${ }^{2}$ in our understanding of the process whereby the young ruminant acquires milk from the udder of its dam. The movement of the suckling's tongue against the hard palate exerts positive pressure on the teat, stripping the milk from it in a manner similar to that of the fingers of the hand milker, suction being a non-essential component of the process. Only the milking machine which obtains milk from the cow solely by the creation of a partial vacuum may, I think, truly be said to suck the cow.

Yours faithfully,

\section{A. T. COWIE}

National Institute for

Research in Dairying,

Shinfield,

Reading RG2 9AT

${ }^{1}$ Cowie, A. T., Folley, S. J., Cross, B. A., Harris, G. W., Jacobsohn, Dora, and Richardson, K. C., Nature, 168, 421 (1951).

${ }^{2}$ For references see review by Cowie, A. T., and Folley, S. J., in Sex and Internal Secretions, third ed. (edit. by Young, W. C.), 1, 627 (Williams \& Wilkins, Baltimore, 1961). 